\title{
The Implementation of Children Friendly City in DKI Jakarta through Assesesment of Children Friendly Integrated Public Space
}

\author{
Dhea Andriani, Urban and Regional Planing, Faculty of Engineering; Pakuan University \\ Indarti Komala Dewi, Urban and Regional Planing, Faculty of Engineering; Pakuan University \\ Janthy T Hidayat, Urban and Regional Planing, Faculty of Engineering; Pakuan University
}

\begin{abstract}
The government of DKI Jakarta province is attempting to build public space to change the city face by means of constructing Children Friendly Public Space (thereafter called RPTRA) as the attempt of supporting Jakarta to be Child-Friendly City. In realizing a Child-Friendly City in DKI Jakarta it is supported by several governor regulations governing RPTRA standardization, RPTRA Management Guidelines, and the DKI Jakarta government also makes Jakarta grand design towards a Child-Friendly City. According to the Governor Regulation Number 196 of 2015, Child Friendly Integrated Public Space is an open place or space that combines community activities and activities by implementing 10 (ten) family empowerment and welfare programs to integrate with child-friendly city program. This RPTRA is part of a child-worthy infrastructure to achieve the fulfillment of one of the 24 child-worthy city indicators set by the Republic of Indonesia Minister of Women Empowerment and Child Protection Regulation Number 12 of 2011 concerning District/City eligible for children Indicators. The government of DKI Jakarta province built 6 (six) RPTRA in Kemayoran, Central Jakarta with each RPTRA having different characteristics. RPTRA Mutiara Sumur Batu has the highest score of 1.66 and RPTRA Harapan Mulya, which is 1.62. The purpose of this research was to assess the suitability and characteristics of RPTRA in Kemayoran District. This research method used GAP analysis, observation, and questionnaire. The results of this research showed that the RPTRA in Kemayoran Subdistrict is still not optimal because only 2 RPTRA have good values, while the other (4 RPTRA) still have constraints in developing RPTRA as fulfilling children's infrastructure.
\end{abstract}

\section{Keywords}

Child-Friendly City, Infrastructur Child Friendly, Public Space

\section{Introduction}

Infrastructure is a matter that is closely related to the conditions of development in the city today, while there are still many infrastructure conditions in the city that have not shown child worthiness. There are many types of talking about infrastructure, ranging from decent homes, transportation, educational facilities, drainage channels, green open space, sports fields, to children's playrooms. Of these, the problem of availability of Green Open Space is a problem that is currently not resolved. 
The development of the Central Business District in DKI Jakarta, especially Central Jakarta from the construction of office buildings, companies, to dense housing on the outskirts of the city, continues to use existing urban spaces. This causes a change in the surrounding environment, especially urban public spaces, and contributes to changing the pattern of community activities in it, so that many settlements are densely populated and the population is quite high in age but lacks public space for children to play.

The importance of fulfilling child-friendly public spaces in realizing Child-Friendly Cities in Kemayoran District, Central Jakarta City can be seen from the large number of children, which is 397,896 people. Reaches $35 \%$ of the population in Central Jakarta City (BPS Jakarta Pusat 2018). So the government needs to make various efforts to improve the quality of children and fulfill facilities and infrastructure facilities that are pro-children in the planning and implementation of government development documents. Child worthy infrastructure is one indicator that must be met by the government in an effort to realize a child-friendly city.

The Government's efforts in realizing the achievement of the Child Friendly City concept are also supported in the Republic of Indonesia Minister of Women Empowerment and Child Protection Regulation Number 12 of 2011 concerning Eligible District / City Indicators. Where in the regulation to develop a Child Friendly City in each district / city, it must refer to 24 indicators of the fulfillment of rights and protection of children which are broadly reflected in the 5 clusters of children's rights, namely (1) Cluster of Civil and Freedom Rights; (2) Family Environment Cluster and Alternative Care; (3) Basic Health and Welfare Clusters; (4) Educational Clusters, Use of Leisure Time and Cultural Activities; and (5) Special protection cluster.

Public open space is a shared space, where the community carries out its functional and ritual activities in a community bond, both daily life and in periodic celebrations that have been determined as something open, where the community conducts personal and group activities. Whereas the Child Friendly Integrated Public Space is an open place and / or space that integrates activities and activities of citizens by implementing 10 (ten) main programs of family empowerment and welfare to integrate with the Child Friendly City program.

Child Friendly Integrated Public Space is also a manifestation of the commitment of the DKI Jakarta Provincial Government to ensure the fulfillment of children's rights so that children can live, grow, develop and participate optimally in accordance with human dignity and receive protection from violence and discrimination. RPTRA can also be described as one of the child-friendly infrastructure in the form of a park designed with a modern concept that is child-friendly, equipped with various supporting infrastructure facilities such as Gazebo / pavilion for children's learning venues, sports facilities, children's forum secretariat, Community Reading Park, internet / wifi network, toilets, etc.

Thus it is expected that Child Friendly Integrated Public Spaces can become the center of public interaction as well as a medium of learning and development of children's interests and talents. With the availability of Child Friendly Integrated Public Space, it is expected to be able to fulfill a playground that is friendly to children and can help in realizing a Child Friendly City, which is a city that is humane, comfortable and friendly to the community, especially children. 


\section{Research Methods}

The study was carried out in 6 Child Friendly Integrated Public Space spread across Kemayoran District, namely RPTRA Harapan Mulya, Krida, Serdang Baru, Bandar Kemayoran, Mutiara Sumur Batu, and Kampung Budaya. The method used in this study is GAP analysis, questionnaire, and qualitative descriptive method. This analysis / Gander Analysis Pathway (GAP) analysis is to find out the gap or conformity between the realization of existing conditions of Child Friendly Integrated Public Space with a model (standards, policies etc.). This can be linked to policies in the RPTRA standardization policy. The calculation formula for the average value of realization of Child Friendly Integrated Public Space is as follows:

$$
\bar{x}=\underline{x_{1}}+\underline{x_{2}}+\frac{x_{3}}{n}+\ldots+x_{n}
$$

Information :

$\overline{\mathrm{x}}=$ average value of realization

$\mathrm{x}=$ Criteria measured

$\mathrm{n}=$ Total RPTRA criteria for overall observation

Whereas to find the calculation of conformity value $(G)$ the following formula is used:

$$
\mathrm{G}=\mathrm{R}-\mathrm{K}
$$

Information :

$\mathrm{G}=$ Average value of conformity

$\mathrm{R}=$ Average score for realization

$\mathrm{K}=$ Value of average policy score

Qualitative methods are research procedures that produce descriptive data in the form of written or oral words from people and behaviors observed (Moleong 2007). As for selecting respondents, the questionnaire was submitted to the RPTRA visitors. Indicator criteria can be seen in the following table.

\begin{tabular}{|c|c|c|}
\hline No. & Variable & Indicator \\
\hline 1. & Accessibility & $\begin{array}{l}\text { - Entrance } \\
\text { - Sidewalks } \\
\text { - Crossing Place }\end{array}$ \\
\hline
\end{tabular}

Table 1 Indicator 


\begin{tabular}{|c|c|c|}
\hline No. & Variable & Indicator \\
\hline 2. & Facilities & $\begin{array}{l}\text { - Multipurpose room } \\
\text { - Library room } \\
\text { - Lactation room and KB space } \\
\text { - Management room } \\
\text { - Family Welfare Development } \\
\text { Room } \\
\text { - Toilet } \\
\text { - Sports fields (futsal/ } \\
\text { basketball / badminton) static } \\
\text { - Chorts facilities } \\
\text { - Rildren's playground } \\
\text { - Punning / jogging track } \\
\text { - An amphitheater } \\
\text { - Garden } \\
\text { - Parking lot } \\
\text { - Park bench }\end{array}$ \\
\hline 3. & Activity & $\begin{array}{l}\text { - Communicate } \\
\text { - Exercise } \\
\text { - Service activities } \\
\text { - RPTRA environment } \\
\text { - Place of community } \\
\text { association }\end{array}$ \\
\hline 4. & Convenience & $\begin{array}{l}\text { - Vegetation } \\
\text { - Distribution of Garden Lights } \\
\text { - Distribution of Trash Can } \\
\text { - Security officer }\end{array}$ \\
\hline
\end{tabular}

\section{Results and Conclusions}

\subsection{Result}

Based on the results of the research, the ideal value for each RPTRA is 2. Where the value of 2 is the result of distributing questionnaires to the community and comparison with the results of expert interviews. Then according to the results of the assessment of accessibility aspects and facilities having higher values because RPTRA is provided to the community, so accessibility is one of the needs that can facilitate the community in reaching RPTRA from its place and facilities are facilities that can support community needs in carrying out their activities or activities while in RPTRA. The results of the conformity assessment on the RPTRA in Kemayoran Subdistrict show that there are only 2 RPTRAs which have good values, while the other 4 RPTRAs still have some obstacles in the development of RPTRA as fulfillment of children's infrastructure. Mutiara Sumur Batu RPTRA achieved the highest rating with a value of 1.66 and RPTRA Krida and Bandar Kemayoran had the lowest rating of 1.42. For more details, can be seen in the following table. 
Table 2. Suitability of Child Friendly Integrated Public Spaces

in Kemayoran District, Central Jakarta

\begin{tabular}{|c|c|c|c|c|c|}
\hline \multirow{2}{*}{ No. } & \multirow{2}{*}{ RPTRA } & \multicolumn{2}{|c|}{ Standar RPTRA } & \multirow{2}{*}{$\begin{array}{c}\text { Facility } \\
\text { Availability }\end{array}$} & \multirow{2}{*}{ GAP } \\
\hline & & Variable & Indicator & & \\
\hline 1. & $\begin{array}{l}\text { Harapan } \\
\text { Mulya } \\
\text { Kel. } \\
\text { Harapan } \\
\text { Mulya } \\
3.446 \mathrm{~m}^{2}\end{array}$ & $\begin{array}{l}\text { Accessibility } \\
\text { Facilities }\end{array}$ & $\begin{array}{l}\text {-Entrance } \\
\text {-Sidewalks } \\
\text {-Crossing place } \\
\text {-Multipurpose room } \\
\text {-Library room } \\
\text {-Lactation room and KB } \\
\text { space } \\
\text {-Management room } \\
\text {-Family Welfare } \\
\text { Development room } \\
\text {-Toilet } \\
\text {-Sports fields }\end{array}$ & $\begin{array}{l}\text {-Multipurpose } \\
\text { room } \\
\text { - Library room } \\
\text { - Lactation room } \\
\text { and KB space } \\
\text { - Toilet } \\
\text { - Sports fields } \\
\text { - jogging track } \\
\text { - Path of } \\
\text { Reflection } \\
\text { - Children's } \\
\text { playground } \\
\text { - An } \\
\text { amphitheater } \\
\text { - Garden } \\
\text { - Park bench }\end{array}$ & 1,62 \\
\hline 2. & $\begin{array}{c}\text { Krida } \\
\text { Kel. Serdang } \\
639 \mathrm{~m}^{2}\end{array}$ & Activity & $\begin{array}{l}\text {-Running/jogging track } \\
\text {-Path of reflection } \\
\text {-An amphitheater } \\
\text {-Garden } \\
\text {-Parkiring lot } \\
\text {-Park bench } \\
\text {-Communicate } \\
\text {-Exercise }\end{array}$ & $\begin{array}{l}\text { - } \text { Multipurpose } \\
\text { room } \\
\text { - Library room } \\
\text { - Lactation room } \\
\text { and KB space } \\
\text { - Toilet } \\
\text { - Sports fields } \\
\text { - Path of } \\
\text { Reflection } \\
\text { - An } \\
\text { amphitheater } \\
\text { - Park bench }\end{array}$ & 1,42 \\
\hline 3. & $\begin{array}{c}\text { Serdang } \\
\text { Baru } \\
\text { Kel. Serdang } \\
1.202 \mathrm{~m}^{2}\end{array}$ & Convenience & $\begin{array}{l}\text {-Service activities } \\
\text {-RPTRA environment } \\
\text {-Place of community } \\
\text { association } \\
\text {-Vegetation } \\
\text {-Distribution of Garden } \\
\text { Lights } \\
\text {-Distribution of Trash }\end{array}$ & $\begin{array}{l}\text { - } \text { Multipurpose } \\
\text { room } \\
\text { - Library room } \\
\text { - } \text { Lactation room } \\
\text { and KB space } \\
\text { - } \text { Toilet } \\
\text { - Sports fields } \\
\text { - Children's } \\
\text { playground } \\
\text { - Path of } \\
\text { Reflection }\end{array}$ & 1,47 \\
\hline
\end{tabular}




\begin{tabular}{|c|c|c|c|c|c|}
\hline \multirow{2}{*}{ No. } & \multirow{2}{*}{ RPTRA } & \multicolumn{2}{|c|}{ Standar RPTRA } & \multirow{2}{*}{$\begin{array}{c}\text { Facility } \\
\text { Availability }\end{array}$} & \multirow{2}{*}{ GAP } \\
\hline & & Variable & Indicator & & \\
\hline & & & can & $\begin{array}{l}- \text { An } \\
\text { amphitheater }\end{array}$ & \\
\hline 4. & $\begin{array}{c}\text { Bandar } \\
\text { Kemayoran } \\
\text { Kel. Kebon } \\
\text { Kosong } \\
586 \mathrm{~m}^{2}\end{array}$ & & & $\begin{array}{l}\text { - } \text { Multipurpose } \\
\text { room } \\
\text { - Library room } \\
\text { - Lactation room } \\
\text { and KB space } \\
\text { - Toilet } \\
\text { - Sports fields } \\
\text { - Children's } \\
\text { Playground } \\
\text { - Path of } \\
\text { Reflection } \\
\text { - An } \\
\text { amphitheater } \\
\text { - Garden }\end{array}$ & 1,42 \\
\hline 5. & $\begin{array}{c}\text { Mutiara } \\
\text { Sumur Batu } \\
\text { Kel. Sumur } \\
\text { Batu } \\
1.202 \mathrm{~m}^{2}\end{array}$ & & & $\begin{array}{l}\text { - Multipurpose } \\
\text { room } \\
\text { - Library room } \\
\text { - Lactation room } \\
\text { and KB space } \\
\text { - Toilet } \\
\text { - Sports fields } \\
\text { - Children's } \\
\text { Playground } \\
\text { - Path of } \\
\text { Reflection } \\
\text { - An } \\
\text { amphitheater } \\
\text { - Garden } \\
\text { - Parkiring lot } \\
\text { - Park bench }\end{array}$ & 1,66 \\
\hline 6. & $\begin{array}{l}\text { Kampung } \\
\text { Budaya } \\
\text { Kel. Utan } \\
\text { Panjang } \\
515 \mathrm{~m}^{2}\end{array}$ & & & $\begin{array}{l}\text { - Multipurpose } \\
\text { room } \\
\text { - Library room } \\
\text { - Lactation room } \\
\text { - Toilet } \\
\text { - Sports fields } \\
\text { - Children's } \\
\text { Playground } \\
\text { - Path of } \\
\text { Reflection }\end{array}$ & 1,44 \\
\hline
\end{tabular}




\begin{tabular}{|l|l|l|l|l|l|}
\hline \multirow{2}{*}{ No. } & \multirow{2}{*}{ RPTRA } & \multicolumn{2}{|c|}{ Standar RPTRA } & Facility & \multirow{2}{*}{ Gavailability } \\
\cline { 3 - 4 } & & Variable & Indicator & \\
\hline & & & & $\begin{array}{l}\text { - An amphiteater } \\
- \text { Garden }\end{array}$ & \\
\hline
\end{tabular}

The characteristics of RPTRA indicate that each RPTRA has its advantages and disadvantages depending on the location and availability of facilities and services provided. The more complete the available facilities and the many RPTRA activities the higher the visitors. RPTRA Harapan Mulya is an RPTRA with the highest activity value because it has the most extensive land and has a lot of service activities compared to other RPTRAs while RPTRA Krida has the lowest value because of limited facilities and limited service activities available.

\section{References}

Manurung, Parmonangan (2018) Kota untuk Semua, Yogyakarta, Andi.

Paratima, Mahditia (2014) Dari Surakarta Mendesain Kota Layak Anak Indonesia, Yogyakarta, HRC Yogyakarta.

Hernowo E; Navastara A.M (2017) “Karakteristik Ruang Publik Terpadu Ramah Anak (RPTRA) Bahari di Kecamatan Cilandak Jakarta Selatan", Jurnal Teknik ITS, Vol.6 (2) Hal: C567C570 (August).

Saidah, Eneng Dayu (2017) "Kebutuhan Taman Kota Ramah Lansia di Kota Bogor", Jurnal Program Studi PWK Universitas Pakuan, Vol 1. No 1 Hal: 1-8 (August).

Sari R.P; Kusumastuti, Putri R.A (2017) “Kesesuaian Taman Cerdas Sebagai Ruang Publik Skala Pelayanan Kelurahan Terhadap Konsep Kota Layak Anak", Jurnal Kesesuaian Taman Cerdas sebagai Ruang Publik, Vol.12 (1) Hal: 72-82 (August).

Widyawati K; Ernawati A, Dewi F.P (2011) "Perananan Ruang Terbuka Publik Terhadap Tingkat Solidaritas dan Kepedulian Penghuni Kawasan Perumahan di Jakarta", Jurnal Ilmiah Faktor Exacta, Vol. 4 (3) Hal: 246-260 (March). 